\title{
Controlled trial of cimetidine in upper gastrointestinal haemorrhage
}

\author{
S. J. LA BROOY, J. J. MISIEWICZ, J. EDWARDS, P. M. SMITH, S. J. HAGGIE, \\ L. LIBMAN, M. SARNER, J. H. WYLLIE, J. CROKER AND P. COTTON \\ From the Department of Gastroenterology, Central Middlesex Hospital, London, the Department of \\ Gastroenterology, Llandough Hospital, Penarth, Glamorgan, S. Wales, the Departments of Surgery and \\ Gastroenterology, University College Hospital, London, and the Gastrointestinal Unit, the Middlesex \\ Hospital, London
}

SUMmARY One hundred and one patients were studied in a double-blind controlled trial to assess the role of oral cimetidine in preventing the continuation or recurrence of acute upper gastrointestinal haemorrhage from various sources, chiefly peptic ulcer. The dose of cimetidine was $800 \mathrm{mg}$ on entering the study followed by $400 \mathrm{mg}$ six hourly. The source of bleeding was identified endoscopically in $96 \%$ of patients, peptic ulcer comprising $70 \%$. Bleeding continued or recurred in 11 of 51 $(21.5 \%)$ of patients on cimetidine and in 12 of $50(24 \%)$ of patients on placebo. Analysis of the effect of cimetidine according to age or severity of bleeding showed no significant advantage for the drug.

Mortality from upper gastrointestinal haemorrhage has remained at about $10 \%$ during the last 30 years (Allan and Dykes, 1976), despite advances in early diagnosis and resuscitation techniques. One of the factors which determines mortality is continuing or recurrent haemorrhage. Various treatments to control or prevent this complication have been investigated, such as gastric hypothermia (Palmer 1969; Simonian and Curtis 1976) and vasoconstrictor agents (Johnson et al., 1976), without much overall success. Laser photocoagulation (Katon, 1976) has yet to be evaluated. The effectiveness of histamine $\mathrm{H}_{2}$ receptor antagonists in preventing bleeding from acute erosive lesions of the upper alimentary tract in severely stressed individuals has been reported previously (MacDonald et al., 1976; MacDougall et al., 1977). It has been suggested that they might have a role to play in upper gastrointestinal haemorrhage due to other causes (Dykes et al., 1977). A multicentre double-blind controlled study was therefore set up to determine whether oral cimetidine $1.6 \mathrm{~g}$ daily would prevent the continuation or recurrence of upper alimentary bleeding.

\section{Method}

Consecutive patients aged 16 years or older, admitted to hospital with a history of haematemesis,

Received for publication 14 June 1979. melaena, or both, in the preceding 24 hours were entered into the trial. Pregnant women and patients with malignancy of the upper gastrointestinal tract, those with renal or hepatic failure, or with bleeding oesophageal varices were excluded from the study. Those whose rate of exsanguination necessitated immediate surgery were also excluded.

Patients were divided into those above or below 60 years of age and each age group subdivided according to the severity of the haemorrhage. Those meeting two of the following criteria: clinical hypovolaemic shock, a pulse rate of $>100 \mathrm{~min}^{-1}$, or a systolic blood pressure of $<100 \mathrm{mg} \mathrm{Hg}$, were considered to have severe haemorrhage; the rest were classified as mild haemorrhage.

After allocation, patients were randomly assigned within each of the four groups to treatment with either oral cimetidine $800 \mathrm{mg}$ immediately and 400 $\mathrm{mg}$ every six hours subsequently, or a placebo of identical appearance. The treatment was continued for a period of seven days. All patients were also prescribed magnesium trisilicate BPC $10 \mathrm{ml}$ (magnesium trisilicate $500 \mathrm{mg}$, magnesium carbonate 500 $\mathrm{mg}$, sodium carbonate $500 \mathrm{mg}$ ) every two hours for the duration of the trial $\left(273 \mathrm{mmol} \mathrm{day}^{-1}\right)$. Emergency endoscopy to ascertain the source of bleeding was performed at a median time interval of 8.2 hours (Range 0-30 hours) after the last episode of bleeding and never later than 36 hours. Management was otherwise according to standard hospital practice. 
Blood for haematological, coagulation, liver and renal function tests was obtained before and at the end of the study. Haemoglobin values were measured daily in all the patients and those with levels below $10 \mathrm{~g} / \mathrm{dr}^{-1}$ were transfused to that figure. Serum cimetidine levels were measured with high pressure liquid chromatography (Griffiths et al., 1977) on the morning of the second study day within four hours of the last dose.

Patients were assessed daily for recurrence or continuation of bleeding, the criteria being haematemesis or the passage of liquid melaena, a marked drop in blood pressure, a rise in pulse rate, or a sudden drop in haemoglobin concentration.

\section{Results}

One hundred and nine patients were entered into the study, but eight were subsequently excluded. One bled from a malignant gastric ulcer, one had renal failure, two absconded before completing the study, and, in the remaining four, there was insufficient evidence of significant haemorrhage.

Of the 101 patients who completed the study, 51 received cimetidine and 50 placebo. The two groups were comparable with regard to age and sex (Table 1). Fifty-five per cent of patients were older than 60 years and the majority of patients in both age groups were classified as having mild haemorrhage (Table 2). Most of the $18 \%$ of patients with severe haemorrhage were more than 60 years old. Previous history of upper alimentary disease was present in $60 \%$ of patients on each type of treatment. Approximately $30 \%$ in each group had taken drugs considered to be gastric irritants-for example, salicylates, steroids, antirheumatic agents-or excessive amounts of alcohol during the preceding week.

\section{SOURCE OF HAEMORRHAGE}

Endoscopic diagnosis of the likely source of bleeding was made in $96 \%$ of patients (Figure). In $55 \%$ the lesion was actively bleeding or showed signs of recent haemorrhage, such as a thrombus in an ulcer crater. In the rest, only one lesion was identified endoscopically in each patient and was assumed to be the source of bleeding. Peptic ulcer was the most common diagnosis, comprising $70 \%$ (duodenal ulcer $39 \%$, gastric ulcer $23 \%$, prepyloric ulcer $9 \%$ ). The various lesions were equally distributed between the two treatment groups.

\section{INCIDENCE OF REBLEEDING}

Of the 101 patients in the trial, $11 / 51(21.5 \%)$ of the patients on cimetidine and $12 / 50(24 \%)$ of the patients on placebo had recurrent haemorrhage. Comparison of the incidence of rebleeding with each treatment in the under and over $60 \mathrm{~s}\left(\chi^{2}=1 \cdot 1\right.$ $\mathbf{P}=\mathbf{0} \cdot 2)$ and in those with mild and severe haemorrhage $\left(\chi^{2}=1.52 \mathrm{P}=0.2\right)$ showed no significant differences. Of patients aged 60 years or older with severe haemorrhage one of six patients on cimetidine and four of eight on placebo rebled, but the numbers are too small to permit meaningful analysis. The incidence of rebleeding in patients with peptic ulcer showed that cimetidine was not significantly better than placebo. None of the six patients with gastric erosions on cimetidine rebled, but two of the three on placebo did.

Table 1 Distribution of patients between two treatment groups according to age, sex, and presence or absence of previous history of gastrointestinal disease

\begin{tabular}{|c|c|c|c|c|c|c|}
\hline \multirow[t]{2}{*}{ Treatment } & \multirow[t]{2}{*}{ Patients } & \multirow[t]{2}{*}{ Male } & \multirow[t]{2}{*}{ Female } & \multicolumn{2}{|c|}{ Age $(y r)$} & \multirow{2}{*}{$\begin{array}{l}\text { Previous history } \\
\text { of GI disease }\end{array}$} \\
\hline & & & & Mean & Range & \\
\hline
\end{tabular}

Table 2 Incidence of rebleeding in patients under and over age of 60 years subdivided according to severity of haemorrhage

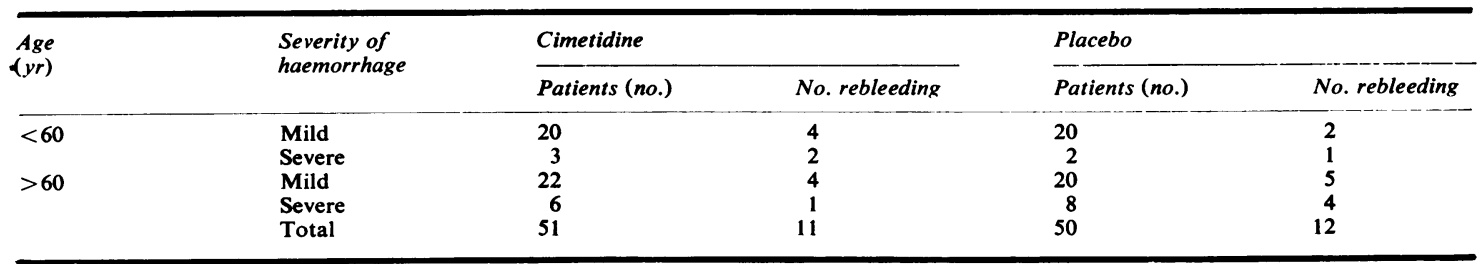




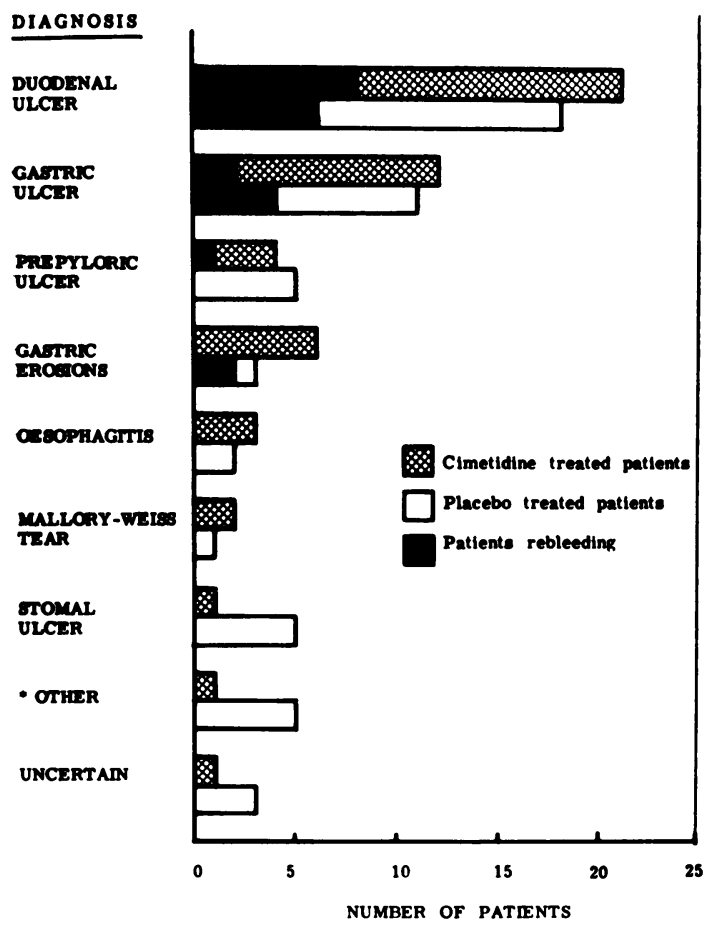

Fig. Incidence of rebleeding in both treatment groups according to the source of haemorrhage. *Including linear ulcer within hiatus hernia, hereditary haemorrhagic telangectasia

The average time of recurrence of haemorrhage from entering the study was $\mathbf{4 4}$ hours for patients on cimetidine and 66 hours for patients on placebo.

\section{EMERGENCY SURGERY}

Six of the 11 patients on cimetidine and seven of the 12 on placebo who rebled needed emergency surgery, all for bleeding peptic ulcers. The only death in the series was a 57 year old male with bronchogenic carcinoma who was treated with cimetidine and who died postoperatively.

\section{SAFETY STUDIES}

Except for anaemia and the initial rise in blood urea to be expected in patients with gastrointestinal haemorrhage, no haematological or biochemical abnormalities were observed after seven days of treatment.

\section{CIMETIDINE ABSORPTION}

Thirty-four randomly selected blood samples obtained within four hours of the morning dose were analysed for serum cimetidine. The mean serum cimetidine concentration in the 13 patients receiving the drug was $3.6 \mu \mathrm{g} \mathrm{ml}^{-1}$ (range 1.9-9.5 $\mu \mathrm{g} \mathrm{ml}^{-1}$ ) well within the $\operatorname{IC}_{50}\left(0.51 \mu \mathrm{g} \mathrm{ml}^{-1}\right)$ of the drug (Brimblecombe and Duncan, 1977). The remaining 21 samples were from patients receiving placebo and in these cimetidine was absent.

\section{Discussion}

Cimetidine has been shown to have a beneficial effect in preventing upper alimentary bleeding in several stressed patients such as those in hepatic failure (MacDougall et al., 1977) or after renal transplantation (Jones et al., 1978). In this study the drug did not effect the outcome of an episode of gastrointestinal haemorrhage, or the incidence of rebleeding in patients, most of whom bled from peptic ulcers. This might be because the effect of cimetidine in haemorrhagic erosions is likely to be mediated by the reduction in mucosal blood flow produced by inhibition of acid and pepsin secretion by cimetidine. This effect, however, is unlikely to influence bleeding from larger vessels present at the base of chronic ulcers.

The incidence of continued or recurrent haemorrhage in the cimetidine and placebo treated patients resembles results in other reports, where no antacid or other therapy were used (Allan and Dykes, 1976). Dykes et al. (1977) have suggested that, although cimetidine may have no advantage over placebo overall, it might be effective in patients with severe haemorrhage or with bleeding gastric ulcers. The majority of the 101 patients in this study had mild haemorrhage from duodenal ulcer. This may have been responsible for the very low overall mortality $(1 \%)$ recorded by us. Another factor was the exclusion of patients with gastric cancer, or oesophageal varices, or those requiring immediate surgical intervention. The incidence of rebleeding in patients with severe haemorrhage or with bleeding from gastric ulcer was less in those treated with cimetidine, though in the former case not significantly so. This suggests that larger series need to be studied to settle this point. In this study cimetidine did not affect the outcome of episodes of haemorrhage by reducing or delaying recurrent bleeding or emergency surgery in mild bleeding from peptic ulcer but additional studies with larger numbers are needed to assess any possible benefits in patients. with erosive gastritis and in elderly patients with severe haemorrhage.

We thank Smith, Kline and French for the supplies. of the drug and placebo used in the study, Mrs C. Ayrton for help in collating the data, and Mrs P. Evans for typing the manuscript. 


\section{References}

Allan, R., and Dykes, P. (1976). A study of the factors influencing mortality rates from gastrointestinal haemorrhage. Quarterly Journal of Medicine, 180, 533-550.

Brimblecombe, R. W., and Duncan, W. A. M. (1977). The relevance to man of pre-clinical data for cimetidine. Proceedings of the 2nd International Symposium on Histamine $\mathrm{H}_{2}$ Receptor Antagonists. (International Congress Series 416), pp. 54-66. Edited by W. L. Burland and M. A. Simpkins. Excerpta Medica: Amsterdam.

Dykes, P. W., Kang, J. Y., Hoare, A., Hawkins, C. F., and Mills, J. G. (1977). Treatment of uppergastrointestinal haemorrhage with cimetidine. Proceedings of the 2nd International Symposium on Histamine $\mathrm{H}_{2}$ Receptor Antagonists. (International Congress Series 416), pp. 337-345. Edited by W. L. Burland and M. A. Simpkins. Excerpta Medica: Amsterdam.

Griffiths, R., Lee, R. M., and Taylor, D. C. (1977). Kinetics of cimetidine in man and experimental animals. Proceedings of the 2nd International Symposium on Histamine $\mathrm{H}_{2}$ Receptor Antagonists. (International Congress, Series 416), pp. 38-52. Edited by W. L. Burland and M. A. Simpkins. Excerpta Medica: Amsterdam.
Johnson, W. C., and Widrich, W. C. (1976). Efficacy of selective splanchnic arteriography and vasopressin perfusion in diagnosis and treatment of gastrointestinal hemorrhage. American Journal of Surgery, 131, 481-489.

Jones, R. H., Rudge, C. J., Bewick, M., Parsons, V., and Weston, M. J. (1978). Cimetidine: prophylaxis against upper gastrointestinal haemorrhage after renal transplantation. British Medical Journal, 1, 398-400.

Katon, R. M. (1976). Experimental control of gastrointestinal hemorrhage via the endoscope: a new era dawns. Gastroenterology, 70, 272-277.

MacDonald, A. S., Steele, B. J., and Bottomley, M. G, (1976). Treatment of stress-induced upper gastrointestinal haemorrhage with metiamide. Lancet, 2, 68-70.

MacDougall, B. R. D., Bailey, R. J., and Williams, R. (1977). $\mathrm{H}_{2}$-receptor antagonists and antacids in the prevention of acute gastrointestinal haemorrhage in fulminant hepatic failure. Lancet, 1, 617-619.

Palmer, E. D. (1969). The vigorous diagnostic approach to upper-gastrointestinal tract haemorrhage. Journal of the American Medical Association, 207, 1477-1480.

Simonian, S. J., and Curtis, L. E. (1976). Treatment of haemorrhagic gastritis by antacid. Annals of Surgery. 184, 429-433. 